\title{
Ductus Venosus Agenesis
}

National Cancer Institute

\section{Source}

National Cancer Institute. Ductus Venosus Agenesis. NCI Thesaurus. Code C111779.

Congenital absence of the fetal ductus venosus. 